\title{
O MAL-ESTAR DO PRESENTE: CONSIDERAÇÕES SOBRE O TEMPO NARRATIVO EM AS ALIANÇAS, DE LÊDO IVO
}

\section{THE DISCOMFORT OF PRESENT TIME: ON NARRATIVE TIME IN AS ALIANÇAS, BY LEEDO IVO}

\author{
Antony Cardoso Bezerra ${ }^{1}$
} Taffarel Bandeira Guedes ${ }^{2}$

\begin{abstract}
Resumo: O romance As Alianças (1947), do escritor brasileiro Lêdo Ivo, tem, no tempo narrativo, o seu principal fator de estruturação. Mais que isso, o tempo é tematizado ao longo de todo o discurso romancístico. Considerando-se instrumentais oferecidos pela Narratologia e tendo por pauta a leitura crítica da obra, estuda-se tanto como é arquitetado o enredo, quanto as maneiras por meio das quais as personagens - em especial, o casal Jandira e José - lidam com o passar do tempo e as angústias de que são acometidas. No sentir das personagens, cuja expectativa é de estabilidade e de certezas, dominam um passado que se revela como airoso, em contraste com um presente e com um futuro de crescente mal-estar.
\end{abstract}

Palavras-chave: As Alianças; Lêdo Ivo; Tempo; Narrativa.

Abstract: Narrative time is a crucial structural aspect of the novel As Alianças (1947), by Brazilian writer Lêdo Ivo. Time, furthermore, is treated as a theme in the novelistic discourse. In order to study the construction of the plot and the ways the characters (mainly the couple Jandira and José) deal with time flowing and the anguish they face because of that, Narratology is employed as a source to a critical reading of the work. The expectations of stability and safety of the characters contrast with a shock between a happy past and a present and a future of discomfort.

Keywords: As Alianças; Lêdo Ivo; Time; Narrative.

"O tempo cura, mas e se o tempo for a doença?" (ASAS, 2007.)

"Tudo, mesmo as pequenas coisas desoladas, devia acontecer, como se o passado, o presente e o futuro formassem uma cordilheira sólida e insolente.” (IVO, 2007, p. 159-160.)

\section{Introdução}

No subtítulo de sua obra-mestra, Mimesis, Erich Auerbach indica o escopo de seu estudo: a "realidade exposta na Literatura Ocidental" (e não a "representação da realidade", como bem salienta Leopoldo Waizbort, 2013, p. 200, ao questionar a tradução brasileira do dito subtítulo). Entende-se, a partir desse princípio, que a obra literária é capaz, ela mesma, de instaurar uma realidade - interna, pode-se chamá-la -, o que

\footnotetext{
${ }^{1}$ Professor Adjunto 3 na Universiade Federal Rural de Pernambuco (Campus Sede), Departamento de Letras.

${ }^{2}$ Licenciando do Curso de Letras da Universidade Federal Rural de Pernambuco (Campus Sede). Bolsista de Iniciação Científica da Fundação de Amparo à Ciência e Tecnologia do Estado de Pernambuco.
} 
implica dizer, de outro modo, que a ancoragem histórica do discurso ficcional não se converta num caráter parasitário em face da realidade em que se baseia e na qual se reinsere. Essa condição insinua um aspecto nuclear para a presente investigação: no plano da figuração literária, o modo como se enxerga o decorrer do tempo, variável de acordo com as diversas cultura e épocas, consiste em condição basilar, mas não definitiva, do estatuto temporal configurado na obra literária. Noutros termos: ainda que se articulem o quadrante histórico em que a obra é produzida e a figuração do tempo por meio dela empreendida, importa verificar por que procedimentos o escritor trabalha a temporalidade em seus diferentes níveis - da narrativa, da fábula, ou, mesmo, como tema.

\section{Discussões}

Por não se descartar, conforme ficou dito, a percepção do tempo e a época correspondente, propõe-se caracterizar um conjunto de aspectos respeitantes ao mundo em que se dá à luz o romance em análise nesta investigação, As Alianças, primeira das escassas obras narrativas do notório poeta alagoano Lêdo Ivo. ${ }^{3} \mathrm{Na}$ arquitetura elaborada pelo escritor, as personagens - sobretudo no que diz respeito a Jandira, protagonista do romance -, numa experiência citadina (o Rio de Janeiro, a grande cidade brasileira da primeira metade do século 20), encontram-se numa encruzilhada de tempos; vivem entre memórias e planos, filtrados por um presente de incertezas, que talvez traduza a amargura do ser no mundo. Retrata-se, assim, um tempo que, numa mirada generalista (mas não por isso indigna de consideração), Adam Abraham Mendilow entendeu desta maneira:

Não parecia improvável, pois, que aquilo que é amplamente referido como "a obsessão do século XX pelo tempo" seja condicionado pelo crescente ritmo de vida, pelo sentido muito difundido da transitoriedade de

3 Mais reconhecidamente poeta do que prosador na cena literária brasileira e internacional, Lêdo Ivo nasceu na cidade de Maceió a 18 de fevereiro de 1924. Sua primeira publicação foi em verso, com o livro As Imaginações (1944). Prova do lugar privilegiado que a poesia ocupa em sua produção são os mais de vinte títulos e umas tantas compilações. Contudo, embora em menor produtividade se comparada ao seu cultivo poético, Ivo também se dedicou à escrita de gêneros em prosa. Publicou cinco romances e alguns livros de contos e de crônicas. Na sua obra romancística, têm direito a destaque os livros As Alianças (1947) e Ninho de Cobras (1973), merecedoras de prêmios literários e de estudos no âmbito acadêmico. Ocupante da cadeira n. 10 da Academia Brasileira de Letras a partir do ano de 1986, o alagoano também se aventurou em textos ensaísticos, na autobiografia - com Confissões de um Poeta (1979) e O Aluno Relapso (1991) - e na produção literária infantojuvenil, em que deu a lume três livros. Dono de uma extensa e abrangente obra literária, Lêdo Ivo faleceu na Espanha, em viagem, no dia 23 de dezembro de 2012. 
todas as formas de vida moderna, e talvez, mais particularmente, pela rapidez das mudanças econômicas e sociais. Estes fatores retiraram do homem aquele sentimento de estaticidade social, aquela certeza de permanência que parece ter marcado períodos de transformação mais confiantes e vagarosos. (MENDILOW, 1972, p. 6.)

Esse quadro, poucas dúvidas há, pode ser relacionado ao do discurso ficcional produzido por Ivo. Para se verificar quais procedimentos narrativos se utilizam em $A s$ Alianças, é relevante, antes de mais, pensar-se nas peculiaridades do gênero literário que o presente estudo tem em vista - o romance. Muito sentido, assim, tem perceber-se como o tempo configurado na ficção, sintonizado com as conjunturas históricas que atravessou, assume feições diversas, em particular, na forma como o autor literário o apresenta. E, por isso, é o caso de se retornar ao já aludido Auerbach, que, no cap. 20 de Mimesis - intitulado "A Meia Marrom" e dedicado, essencialmente, a Virginia Woolf, Marcel Proust e James Joyce -, faz ver que os expedientes empregados pela escritora inglesa, em Ao Farol, já não consistem numa reedição do que realizações do romance europeu no século anterior, o 19, alcançaram. O filólogo explica: se, no plano de Madame Bovary, de Gustave Flaubert, "conservava-se sempre o escritor, com o seu conhecimento da verdade objetiva, como instância suprema e diretriz." (AUERBACH, 1976, p. 483); em Ao Farol, "O escritor, como narrador de fatos objetivos, desaparece quase que completamente; quase tudo o que é dito aparece como reflexo na consciência das personagens do romance." (AUERBACH, 1976, p. 481.) Talvez se possa definir essa distinção nos termos do que Adorno foi capaz de observar ao distinguir o modo realista de produção ficcional conforme configurado nos séculos 19 e 20, quando, neste, para "[...] dizer como realmente as coisas são, [o sujeito narrativo] precisa renunciar a um realismo que, na medida em que reproduz a fachada, apenas a auxilia na produção do engodo." (ADORNO, 2003, p. 57.) Não que o procedimento de Woolf seja inédito per se; é que, na verdade, da maneira como realizado pela ficcionista, deixa de repousar numa só personagem (que, usualmente deteria a enunciação numa narração autodiegética) para disseminar-se pela narrativa, num discurso elaborado por meio da terceira pessoa gramatical, mas entremeado por juízos de caracteres; não apenas de um. Nas palavras de dois narratólogos, no mundo em apreço, "[...] o tempo já não é o rio ou o círculo mítico, mas espelho estilhaçado em mil pedaços ou parcela microscópica: as 'miríades de impressões'”; ou, ainda, “[...] o tempo já não é apenas um tema ou a condição duma realização, mas o próprio assunto do romance." (BOURNEUF \& OUELLET, 1976, p. 179; p. 170.) 
A condição do tempo conforme problematizada a partir do século 20, não há dúvida, diz respeito a As Alianças; e não apenas pelo enquadramento epocal. No entanto, antes de se detalharem os recursos de Ivo e os respectivos efeitos, cumpre precisarem-se os níveis em que a esfera temporal se pode compreender na estrutura literária; noutras palavras, é necessário responder-se à questão: de que tempo se está falando? Por superar o ranço imanentista dos estudos da narrativa de arcabouço formalista, Cesare Segre (1986) apresenta-se como um norte válido à oferta de respostas. Nele, modelos de análise da narrativa são comentados e relativizados em seu raio de alcance, o que conduz o semioticista à percepção dos

[...] principais motivos que impedem [...] a criação de um modelo narrativo geral, isto é, de um catálogo fechado de funções e de regras para sua combinação: a mediação imprescindível do resumo - que tem natureza inevitavelmente subjetiva - para a passagem de uma fabula qualquer à estrutura funcional; a falta de um sistema narrativo global, que permita individuar as unidades mínimas mediante comutação: o pesquisador deve, de cada vez, assumir como sistema o próprio texto, ou um corpus de textos ligados por alguma afinidade cronológica ou conteudística ou temática etc.; a impossibilidade de estabelecer uma distância uniforme de generalização entre o léxico deste repertório e a série extensa de ações reais que cada número do repertório deveria assumir. (SEGRE, 1986, p. 82.)

Depois da visita a narratólogos como Chklóvski, Tomachévski, Propp, Todorov e Greimas, Segre verifica a eficiência apenas parcial das propostas de análise da narrativa; parcial, sobretudo, por um fator: aos textos que serviram de base à extração de um modelo é que este efetivamente diz respeito, pois, de outra maneira, o que se alcança são abordagens que menos ganhos trazem à leitura analítica do texto narrativo, de vez que a especificidade das obras é prejudicada seja pela generalidade do modelo, seja pela eventual arbitrariedade de sua aplicação. Somente considerando-se a relação entre texto e conjuntura - na superação de uma exegese imanentista e bem à maneira da Filologia Moderna de Auerbach - torna-se frutuoso o aproveitamento dos "modelos propostos (e melhor ainda os construtíveis), que ameaçavam resultar em instrumentos de dúbia utilidade [; assim, eles] podem ser recuperados, e revelarem-se preciosos, se usados não como modelos da narrativa, mas como modelos de leitura de textos narrativos." (SEGRE, 1986, p. 83.)

Aceitando-se essa lição, é lícito acreditar que As Alianças, em suas anacronias narrativas, cobra a ciência de uma das distinções caracterizadas por Segre, aquela realizada entre "discurso", que é o texto narrativo em sua faceta significante; "enredo", 
que consiste no conteúdo do texto conforme apresentado na narrativa; e, por fim, a "fábula", que se apresenta como o conteúdo do texto apresentado numa reorganização tanto lógica quanto cronológica (SEGRE, 1986, p. 12). Atente-se para o fato de que a fábula não consiste, como se poderia pensar, num dado; antes, assume a condição de resultado de uma operação que não deixa de ser subjetiva, pois o leitor (diletante ou analítico) seleciona os eventos que, em relações de causa e efeito, parecem-Ihe ser essenciais para que a história se conte. Vale assinalar que essa separação de níveis é muito mais procedimental que inerente, mas isso não rebaixa a sua importância. Para fins de análise, a distinção em pauta torna possível perceber-se o que os descompassos entre os níveis podem acarretar, tanto em termos da percepção da fábula, quanto do que o artista pode alcançar ao trabalhar diferentemente as esferas temporais.

Mesmo que nos atenhamos unicamente ao aspecto narrativo, nota-se de fato que ao leitor é proposto um duplo trajeto de significação: do trajeto que o discurso narrativo oferece com suas deslocações e seus cruzamentos, o leitor descobre progressivamente o trajeto temporal, reconstitui um acontecimento que apreendeu segundo a ordo artificialis escolhida pelo escritor. É esta a forma mais geral e importante do estranhamento: por seu intermédio acrescenta-se, à aventura depositada na narração, a aventura do ato de ler; a ordem e o modo em que os fatos são levados ao conhecimento do leitor são tais que potenciam e polarizam em um sentido particular o valor. (SEGRE, 1986, p. 35.)

No caso de As Alianças, essa condição se patenteia por meio de vários expedientes, conforme adiante se detalha - seja nas analepses (recuos no tempo) e prolepses (antecipações no tempo), seja na duração, possível chave para a compreensão da relação das personagens com o tempo e, mais amplamente, com a própria vida. Para se perceber a dilação entre os planos indicados, importa o entendimento do que Segre chama de "segmentação" entre enredo e fábula, que consiste em "1) [...] individuar segmentos discursivos compactos, mas considerando também eventuais mutações na maneira de comunicar o conteúdo; 2) [...] distinguir segmentos de 'ação' de segmentos descritivos, meditativos, históricos etc.; 3) [...] individuar as peculiaridades linguísticas destes segmentos." (SEGRE, 1986, p. 36.)

Para arrematar a especulação em torno das bases à análise da realidade exposta em As Alianças e os expedientes de apresentação do tempo na narrativa, vale ter-se em conta uma última pontuação do semioticista: "É preciso, enfim efetuar uma operação prévia: caracterizar a lógica (intertextual) das ações num determinado corpus (que cabe em um estatuto histórico, controlável no contexto)." (SEGRE, 1986, p. 63.) O conjunto de fatores dispostos pelo romancista tanto não é aleatório, quanto, ainda mais, é essencial 
para se compreender a exposição dos eventos e das personagens. Sem se compreender a mecânica do tempo narrativo, torna-se penoso - quase impossível - o entendimento das implicações que o modo de contar (enredo) traz ao que se conta (fábula). Nesse sentido, a análise de As Alianças em face de um mundo, não tanto em termos de exposição de uma realidade (a de meados do século 20 na cidade capital do Brasil), mas, sim, da instauração de uma realidade alternativa, ficcional, revela-se como operação capaz de elucidar os desdobramentos que as anacronias narrativas podem trazer à leitura do romance.

A fortuna crítica de Lêdo Ivo como ficcionista é um reflexo do precário (re)conhecimento que a sua obra em prosa alcançou entre os leitores comuns e, mesmo, entre a crítica acadêmica. Pouco se dissertou sobre seus romances dentro dos estudos universitários, enquanto que a sua poesia é objeto constante de investigações, o que traduz o seu maior prestígio como poeta. Dentro das investigações sobre seu universo ficcional, deve-se assinalar a tese de Márcio Ferreira da Silva, na qual o ambiente geográfico é analisado em duas narrativas. Intitulado A Geografia Literária de Lêdo Ivo: a cidade nos romances As Alianças e Ninho de Cobras, esse estudo trata do espaço literário como um fator atuante na composição e decomposição do ambiente, da ação narrativa e das personagens. Diz Silva:

[...] o espaço integra de inúmeras maneiras a composição do ambiente e torna a descrição não instrumento [sic] alegórico que caracteriza a forma romanesca, mas elemento que assume com elegância e estilo o tom de certas narrativas, como se essa categoria fosse foco importante da representação do real, [...]. (SILVA, 2007, p. 11.)

Esse elemento narrativo é reconhecido como influente nos dois romances comentados, nos quais o espaço não é um instrumento acessório em função da ação e dos demais constituintes da narrativa, mas um instrumento que opera sobre eles. Com efeito, é patente, em As Alianças, a maneira como os diferentes espaços, em especial Serra Branca $^{4}$ e o Rio de Janeiro, estão relacionados com as angústias e inadaptações das

4 Cidade brasileira empírica com o nome de Serra Branca há apenas uma, no Estado da Paraíba. Àquela de que provém Jandira é referida, no corpo do romance, como situada em Minas Gerais (IVO, 2007, p. 245); é de lá que, por transporte ferroviário, Jandira parte rumo à capital federal (IVO, 2007, p. 14). O fato é que a Serra Branca romanesca cumpre plenamente sua função dentro da narrativa: a da cidade pequena que se constitui, também, como um espaço da memória. 
personagens. Quando no interior, Jandira sonha com a vitalidade carioca, com grupos de amigos e agitados espaços de convivência; quando na capital, pouco se afaz ao ambiente, encarando-o por vezes com indiferença, ocupada com outros pensamentos, como lembranças de Serra Branca. A mudança dos espaços interfere, portanto, no estado íntimo da personagem: seus pensamentos, sonhos e sentimentos. Num romance que tem como principal fio condutor o intimismo das personagens, isso intervém diretamente na maneira como a ação narrativa é desenvolvida.

As Alianças, quando de sua publicação, foi condecorado com o prêmio de romance da Fundação Graça Aranha. Entrementes, conforme indiciado, não é tendência dominante a história de Jandira e José ter recebido, desde seu lançamento, o reconhecimento da Crítica Literária que da obra se ocupou, apesar das qualidades literárias de Ivo, que, conforme ora se sustenta, não se restringem às produções em verso. Um bom exemplo dessa reserva advém de outra esfera que não a brasileira. O Prof. Lee Hamilton, da Universidade do Texas, publicou, em 1948 (um ano após, portanto, o lançamento do romance de Ivo), uma "Amostra da Literatura Brasileira Recente" (HAMILTON, 1948), em que é feito um comentário geral dos fatos literários - publicações, republicações, passamentos etc. - dos anos do Pós-Guerra no Brasil. Dentre as obras discutidas pelo crítico - produzidas, segundo ele, sob a égide de uma situação tumultuosa política e economicamente, que bem se traduziria no termo "precário" -, está a narrativa do escritor alagoano, que se enquadra numa tendência dominante na ficção do país:

[...] há um crescente interesse, por parte dos escritores brasileiros, no romance psicológico ou "metafísico"; o "romance dramático", conforme o chamou, com certo teor de engano, Otto Maria Carpeaux. O nome mais usualmente associado a esse tipo de composição, no Brasil, é o de Lúcio Cardoso, cujo melhor livro recente talvez seja a novela Inácio, precisamente por ser a menos pretensiosa. Afinal de contas, não é nesse tipo de escrita que o gênero propriamente dito atua como uma espécie de lente que amplia quaisquer deficiências e tende a as distorcer numa aparência de insinceridade, numa espécie de esforço barato pelo efeito fácil? Isso talvez explique a insatisfação que se possa ter com duas recentes estreias em romance de jovens autores. [...] em 1947, veio a lume As Alianças, de Lêdo Ivo, uma representação da espera humana por escapar de uma solidão espiritual. [Tradução própria.] (HAMILTON, 1948, p. 506.)

Ainda que veja qualidades na ficção de Ivo - registre-se que a outra escritora em foco é Maria Julieta Drummond de Andrade, filha do poeta e cronista Carlos -, Hamilton acredita que a opção dos escritores brasileiros psicologizantes acaba por expor a nu as suas próprias limitações, quase como um passo além das próprias pernas. Não é o que, de 
outro lado, pensa o poeta e crítico literário Gilberto Mendonça Telles (apud ANDRADE, 2010 , p. 6), que viu, nesse primogênito, qualidades técnicas análogas às dos melhores romances ingleses do século 20, a exemplo as produções de Virginia Woolf, Rosamond Lehmann e James Joyce; produções essas tão influentes sobre a Literatura feita no Brasil a partir dos anos 1940. Telles descreveu a obra de Ivo como "um romance das ilusões perdidas", muito bem definindo o estado das personagens na trama.

Com uma trama que tem como personagem principal a resignada e melancólica Jandira, As Alianças seria um romance de busca pela realização. Em seus 12 capítulos, acompanha-se uma jovem que viveu a infância e parte da juventude na pacata cidade de Serra Branca. Trata-se de um contraste já assinalado por Silva, segundo quem "O romance As Alianças explora o espaço urbano, sem perder de vista o encontro entre a cidade imensa e a pequena cidade do interior, cuja lembrança das personagens nos remete o narrador.." ${ }^{5}$ (SILVA, 2007, p. 87.) A tranquilidade e o marasmo do interior, com os hábitos que não se alteram, as poucas opções de entretenimento, entediavam-na e faziam com que sonhasse com o grande centro urbano que era o Rio de Janeiro. Afinal, "que poderia fazer ali? Apenas casar-se e ter filhos, envelhecendo em silêncio." (IVO, 2007, p. 12), é o que se pondera, num recuo da narrativa. A moça do interior realiza esse seu desejo e passa a viver na então capital federal. Deslumbra-se com o mar, com os modos e as modas da metrópole e tenta entrar no Conservatório para o estudo de música. Contudo, os dias passam, e a personagem se vê novamente envolva em reflexões sobre a inércia em que se encontra: "Nos dias em que não ia à cidade, Jandira se entregava a reflexões sobre a sua vida. Seria possível que a vida corresse eternamente assim, rio de águas sempre iguais?" (IVO, 2007, p. 27). Mais uma vez, põese a projetar o que the tranquilizaria o espírito: "Um dia ela moraria num apartamento em Copacabana, junto ao mar - e ouviria, ao cair da tarde, cantos de cigarras e apitos de navios." (IVO, 2007, p. 27). Note-se que, nessa série de excertos, é o narrador, que desce ao ponto de vista da personagem, o responsável por verbalizar-Ihe o que vai no íntimo, numa revelação que talvez nem mesmo a própria personagem compreendesse com tal clareza. Mais adiante no enredo, Jandira se casa com José, mas frustra-se na vida monótona que leva como dona de casa. No juízo de Silva,

Jandira [...] se modela no vazio, na solidão, no desencontro. Isso a faz manter características de personagens que, aparentando um centramento

5 A referência a "as personagens", no plural, justifica-se por, conforme se vê no decorrer dos comentários, não se limitar a Jandira a vivência anterior num universo campesino. 
- o casamento poderia ser entendido dessa forma -, apenas se reconhecem fora desse eixo, no descentramento. (SILVA, 2010, p. 56.)

Também a vida do seu marido se desenrola entre reminiscências e projeções, ficando o presente suplantado em importância na consideração das personagens. No que alcançam e no que fracassam, Jandira e José permanecem infelizes, numa urbe ricamente explorada em seus tipos humanos e espaços. Para Silva (2007, p. 87), "é o espaço urbano [...] ponto-chave da ação no romance, cujas personagens se revelam ou procuram se revelar na relação com a cidade." No mundo citadino e presente, encontrase a charneira por meio da qual o par de caracteres recorre à memória da vida passada e pensa incessantemente no futuro. Dessa forma, o presente tedioso é explorado em conjunto com as recordações e os projetos que formatam a constante da vida do casal.

Conforme já sugerido, o tempo consiste não apenas num fator estruturante de As Alianças, mas é, também, um elemento amplamente tematizado na economia do romance, pois revela as angústias das personagens mais importantes - o casal Jandira e José -, numa demonstração articulada da condição humana. A própria narrativa une os tempos, se se considerar que o capítulo 1 , do ponto de vista da fábula, não denota uma ordem cronológica, funcionando como um in media res. Os descompassos temporais são aguçados não apenas pela ordem da fábula conforme disposta no enredo - i. é, pelo seu desenvolvimento nos capítulos -, mas também pelas reincidentes analepses e pelas projeções que as personagens fazem: do passado que se transforma em presente e deste a um futuro que tende a não se concretizar na fábula. No sentido de deslindar esse processo pontualmente, é o caso de se visitarem expressamente algumas poucas passagens ilustrativas do texto literário, acompanhando a elaboração das personagens como condicionada muito nitidamente por sua colocação no tempo e reflexões, sobretudo de Jandira e de José, acerca dessa esfera.

Muito sintomaticamente de tudo o que se tem sustentado, a primeira oração do capítulo 1 é "A festa era no dia seguinte [...]." (IVO, 2007. p. 8.) Está-se na llha do Governador e num momento da fábula que se apresenta como antecipado na narração; ou seja, trata-se de uma prolepse. Vários amigos estão reunidos para uma festa e, sobre eles, poucas informações se tem a esta altura. O presente se apresenta como uma espera e viver em função do futuro - próximo ou distante, não importa - é sentimento que parece consumir Jandira, que confessara a José, no momento em que o futuro namorado e marido a deixa no Cais Pharoux para tomar a barca que a levará ao destino: "O triste, em uma véspera de festa, é que só vivemos para o dia seguinte." (IVO, 2007, p. 9.) E essa percepção 
desdobra-se em não poucos níveis, de vez que, indagada pelo amigo Moacir sobre se está gostando da estadia, evade-se, ainda que tenha os pensamentos desvendados pelas palavras do narrador:

Ela estava em uma ilha, e era como se se encontrasse em um continente qualquer. Em Serra Branca, muitas vezes desejara ilhas. Também tudo isso era porque queria fugir, deixar sua mãe, substituir a piscina onde nadava por um mar autêntico, conhecer uma grande cidade que não the sufocasse os sonhos. (IVO, 2007, p. 8.)

A "grande cidade", no caso, é o Rio de Janeiro da déc. de 1940, um oásis de tranquilidade num mundo em guerra. A experiência de Serra Branca é apenas aquela que a exposição direta proporciona - da piscina que é o orgulho da cidade, das leituras de romances, das brincadeiras em família e de uma forte presença da religião, que Jandira reluta em aceitar (IVO, 2007, p. 11-14). A do Rio de Janeiro, por seu turno, vai assumir uma condição que é, no mínimo, de duas faces: a da projeção e a da vivência. A primeira é a que Jandira vislumbra em Serra Branca, com o sonho de estudar música e a possibilidade de nadar no mar azul, já que, "Nos filmes, via às vezes trechos de Copacabana. Eram rapazes pedalando bicicletas, moças vestidas de maiô, toldos armados na areia, edifícios enormes, ondas quebrando-se na praia. Sim, tudo isso a chamava." (IVO, 2007, p. 14.) A segunda face é a que vai se constituir como a matéria ela mesma do romance, o choque entre as expectativas inocentes da moça interiorana e a descoberta de que aquilo que se deve resolver interiormente - busca da felicidade ou da paz consigo mesma? -, é evidente, não vai encontrar remanso em agentes externos. O primeiro constrangimento à realização dos sonhos vem da condição financeira - sem dinheiro suficiente e morando em casa de Tia Palmira de favor, Jandira se desnorteia: "O tempo ia passando, já fazia quase um ano que ela deixara Serra Branca e não tomara ainda nenhuma resolução.", salvo a de deixar de lado o sonho de entrar no Conservatório, que "[...] era impossível." (IVO, 2007, p. 18; p. 19.) No presente, leva uma vida diletante, atravessada por algumas memórias e planos que já não consegue dimensionar com clareza. Vive em função de um passado irrecuperável ("[...] algo profundo em sua pessoa se estava modificando. [...] teria de ficar sempre no Rio, longe de Serra Branca."; IVO, 2007. p. 20) e de um futuro que sequer consegue sonhar, pois que sem destino. O que resulta dessa tensão irresolvível? A amargura de um presente que não pode (nem deve) reeditar o passado e de um futuro que consiste em não se sabe que sonho, que não se sabe para quê; vive-se em função de duas quimeras. 
A uma altura do romance, Jandira se põe a contemplar a passagem do tempo: "Sabia que, em todas as partes do mundo, os relógios estavam avançando, em direção a uma hora que não existia, que eles procuravam sem jamais encontrar." (IVO, 2007, p. 107). Nesse momento da narrativa, a ação é suspensa para que se realize a descrição da divagação da personagem. Jandira não pensa noutra coisa senão no transcorrer do tempo e nos efeitos que provocará em si. Tem ciência de que a inexorável marcha do tempo modificará seu corpo, fará ausentes os presentes em sua vida. Tudo caminha para a morte no decurso temporal. O tempo presente da personagem, portanto, é ocupado com uma digressão meramente contemplativa, sem ação narrativa definida. Se é verdade que Jandira ocupa as suas horas fazendo planos para o seu futuro ou recordando o passado, na altura em apreço, chega ao extremo de preencher os instantes com reflexões sobre os próprios instantes, num apogeu da ociosidade.

Sobre a organização temporal do romance, vale insistir em que a ordem dos eventos na narrativa não é cronológica, sendo elaborada a partir de anacronias. Dentro da conceituação haurida em Segre, pode-se afirmar que o discurso dispõe o enredo sem ordem cronológica, e a fábula é fragmentada nas três esferas temporais, de vez que não há um passado, um presente e um futuro - pulverizam-se as vivências (e as expectativas) a partir de um presente, ele mesmo, desarticulado. Vale assinalar, entrementes, que o vai-e-volta temporal identificado se estabelece no plano psicológico das personagens, pois a cronologia da narrativa, mesmo não sendo linear, avança e recua constantemente, sobretudo, a partir da mente de Jandira e da de José. A experiência das personagens com o tempo tem o seu reflexo, inclusive, no plano do discurso, ainda mais se se entender que a extensão dos capítulos (sui generis em sua variação, para dizer o mínimo) tem íntima relação com a natureza dos elementos fabulares que se relatam. Quem muito bem desvendou essa condição foi Silva, ao afirmar:

O romance As Alianças é composto de doze capítulos, que se organizam essencialmente entre nove e dezenove páginas, mas, contrariando essa organização, os capítulos dez e onze têm, respectivamente, trinta e cinco e noventa e seis páginas. Pode parecer uma escolha da autoria a dimensão dos capítulos, todavia, esse fato pode revelar um universo avesso à união: a solidão.

[...] é possível observar que o capítulo nono contém só cinco páginas. Seria um simples acaso se o referido capítulo não tratasse do título do romance: aliança; união; o casamento, ou a viagem de núpcias, de José e Jandira. (SILVA, 2007, p. 88-89.)

Longe de se constituir como acaso, a dimensão que assumem os debruçamentos do narrador sobre as experiências da personagem é reveladora do grau de importância que 
ocupam na alma das personagens; e poucas dúvidas restam, assim, de que a da angústia assume ares de dominação.

O romance tem a onisciência seletiva como foco narrativo, sendo o enredo inundado pela visão de mundo, pelo tédio e pelas meditações das personagens - marcantemente, do casal protagonista - sobre passado e futuro, tornando-se um reflexo do seu enfadado cotidiano. Veja-se um trecho do capítulo 10, em que as personagens já se encontram casadas:

Jandira não sabia que José também tinha seus momentos de apelo ao passado. Estavam jantando ou sentados na sala de jantar, ele às voltas com um livro e ela folheando um jornal, e de súbito José se deixava envolver pela presença de Jandira. Olhando sua mulher, com os cabelos soltos, o nariz fino, os olhos brilhantes, ele voltava a escutar a voz de um amigo, quando Ihe participara sua vontade de ficar noivo: "Você bem sabe que ela não é bonita." José apresentara algumas justificativas mornas, e o outro continuara: "Ela é engraçada, agradável. Bonita, não." Contemplando-a, assaltava-o uma grande ternura. Novamente a voz do amigo: "Você não gosta dela. Faz força para gostar." Era-lhe difícil afirmar que a amava; acostumara-se a ela, incorporara-a à sua vida, e jamais se libertaria de Jandira. (IVO, 2007, p. 122.)

No trecho, tem-se o retrato de um instante da vida em comum de José e Jandira. A narrativa muda de perspectiva, saindo de Jandira e partindo para José, que, assim como sua mulher, também "tinha seus momentos de apelo ao passado." A incomunicabilidade entre ambos, o automatismo do jantar e o silêncio da leitura que cada um praticava individualmente ilustram o ócio do casamento, levando José, ao olhar para Jandira, mais uma vez voltar ao passado. José volta ao passado e reflete sobre seu relacionamento: amaria Jandira, ou teria apenas se afeiçoado a ela? A voz passada do amigo e os argumentos "mornos" de José levam a crer que ele incorporou Jandira à sua vida, acostumando-se a ela e estando aprisionado à presença da esposa pelo resto de seus dias, pondo em foco mais uma vez o seu futuro.

Se o passado mais distante de Jandira remonta a Serra Branca, o de seu marido antes namorado - situa-se, inicialmente, num sítio das Alagoas. É após a festa que José, em conversação com Jandira, falará longamente sobre "A infância, esse tesouro incômodo e jamais de todo enterrado, [que] voltava nas suas palavras." (IVO, 2007, p. 82.) Está-se no capítulo 7 e, deste momento em diante, sucede-se, por meio de palavras de José (o que se indica por meio das aspas) a caracterização de vários eventos dos tempos idos, dos pais, dos irmãos, das brincadeiras, dos bichos de estimação... As 
reminiscências das menores coisas - num gosto vagamente proustiano - permanecem vivas na mente (e na voz) de José:

Vestido de casimira azul, uma pasta enorme, pendendo-lhe da mão direita, papai ia para o trabalho. Beijava-nos e prometia presentes que nunca trazia, mas tinham o poder de encher-nos a imaginação. Do portão, nós o víamos caminhar pela estrada larga, marginada de sítios, galhos desabando fora das cercas. Ele ia se tornando cada vez menor, até desaparecer na curva. Às vezes, voltava-se antes de desaparecer, e deixava no ar um gesto de adeus. Outras vezes, como se se esquecesse de nossa presença, desaparecia sem nos acenar. Ficávamos tristes, vinha entretanto a alegria, porque o sítio nos convidava para passeios sem fim. (IVO, 2007, p. 85.)

$\mathrm{Na}$ infância, só o sonho já é capaz de preencher a alma; e é nesse mundo de promessas que a personagem busca algum remanso que a motive a continuar vivendo. $\mathrm{E}$ a tristeza é efêmera, porque a ausência de compromisso - diferentemente do que se dá no mundo adulto - logo torna tudo simples, facilmente resolvível. Esse recuo temporal acaba por equiparar a situação de José à de Jandira, tanto pela anacronia narrativa, quanto pelo que significa a infância em face do presente: uma espécie de paraíso perdido que só pela memória se pode recuperar; jamais em experiência direta. Após o extenso trecho em que a palavra é de José (e a ouvinte é Jandira), o narrador retoma as rédeas do contar e o tom do discurso perde o seu lirismo, o seu ar de confissão; três páginas depois (IVO, 2007, p. 90), restabelece-se a voz das personagens, agora, em efetivo diálogo que se trava entre os jovens enamorados; por fim, tem-se fragmentos "Da narração de José" (IVO, 2007, p. 94-97), que se findam com o conhecimento da morte de uma criança que, numa das ruas próximas de onde se realiza a festa, agonizava. Tratase do menino Juquinha, cujo passamento se efetiva no capítulo 6 e cuja morte coincide com o termo da festa. O passado de José, por seu turno, é desenhado como um quebracabeça com peças de diferente valor e compostas por diferentes materiais. A vida, aqui, converte-se na capacidade de comunicação, como muito bem parece entender Jandira: “José, o que será de nós no dia em que nada tivermos para contar um ao outro?", ao que responde José: “- Nada. Continuaremos a caminhar em silêncio.” (IVO, 2007. p. 98.) Contrastando as experiências passadas com o desconforto do futuro que o aguarda, "Agora, José tinha medo do tempo. Que destino seria o seu? [...] Que significava a própria vida que o esperava, lá fora?" (IVO, 2007, p. 99.) Profético desencontro, que, no capítulo 11, confirma-se em tom mofino. Logo após o enlace, lê-se: 
O casamento fora decepcionante para Jandira. Dera-lhe uma estabilidade, fizera-a repousar, mas fora obrigada a renunciar a tantas coisas! Não que sentisse sua liberdade tolhida, mas tinha sido obrigada a adotar uma nova forma de liberdade. Não era mais uma menina. Além do mais, sabia que José, conhecendo sua vida e tudo que a caracterizava, a compreendia em silêncio. (IVO, 2007, p. 123.)

Já presente, o silêncio projetado na conversa após a festa começa a incomodar. As incertezas quanto ao futuro são um tormento constante para Jandira. Por palavras do narrador, especulara: "[...] e se José um dia a abandonasse, cansado de seu silêncio e de seus súbitos contentamentos? E se uma outra mulher the desse um filho? Jandira estremeceu. Sentia medo: José representava a sua única ligação com o mundo e a vida." (IVO, 2007, p. 181). São algumas das questões que assaltam Jandira, pondo em foco a instabilidade do seu casamento com José. Casamento que se mostra tedioso e aberto às divagações da personagem, que preenchem cada vez mais o romance. $\mathrm{O}$ trecho consta do capítulo $11 \mathrm{e}$, aqui, é explorado o cotidiano do casal. O ambiente da casa e tudo o que atinge o sensorial da esposa incitam as suas divagações. Por vezes, detalhes ínfimos como o som da chave na fechadura ganham significado numa vida que se arrasta em meio à vacuidade da espera diária pelo marido. Contudo, apesar de um casamento em que pouco se vive e aproveita, Jandira enjeita a possibilidade de um rompimento, porque José era o seu laço com o mundo e a vida (IVO, 2007, p.182). Por ele esperava e nele sentia a segurança que daria a um ser vulnerável como ela a proteção do horror da vida, só assim ficando tranquila. José, por seu turno, via em Jandira o refúgio a que sempre poderia recorrer para o seu repouso. A união, portanto, de um abrigo estável e um refugiado, condicionados pelo que buscavam um no outro.

Ainda assim, o silêncio passa a vigorar com mais nitidez quando do envolvimento do marido com a personagem Vera; à altura, Jandira se sente oprimida não apenas pela falta de comunicação, mas, também, pela traição. Na voz do narrador, desnuda-se tudo o que vai no íntimo da moça de Serra Branca:

Somos mentira e impostura. E passamos a vida inteira aplicados em esconder dos outros, em subtrair dos olhares que nos interrogam, os tesouros miseráveis sepultados no fundo de nossos corações.

$E$ ao silêncio de agora correspondia outro silêncio, que José jamais poderia voltar a atingir, por mais que atravessasse cidades e ruas, pontes e jardins, embora os dias acumulados não tivessem conseguido dissolvêlo. (IVO, 2007, p. 216.)

Muito diferente é o sentimento do presente - nunca se deve esquecer, desenvolvido num capítulo de noventa e uma páginas (IVO, 2007) - do momento, efêmero e feliz, de 
quando se casaram Jandira e José; no capítulo 9, lê-se: "Não se esqueceria nunca do casamento. Fora um dia de ansiedade e alegria, e [...] se surpreendera com o fato de poder ser tão assustadoramente feliz no espaço de algumas horas." (IVO, 2007. p. 112.) A felicidade ou reside num passado que vive apenas como lembrança, ou num presente que se configura como um fogo fátuo, incapaz de amortecer os males do mundo.

Para além das duas personagens que protagonizam a narrativa, mais de uma secundária revela preocupações com o tempo e não abre mão das recordações. O capítulo 5 - em que ainda decorre a festa da llha do Governador - acaba por ser um ponto de partida para que venha à tona o passado dos caracteres e sua presença num presente de angústias e dúvidas. É bem o caso de Rodolfo (um amigo do casal Jandira e José), cuja chegada à capital federal é rememorada pelo narrador: "Desde que viera para o Rio, procurara alguém que Ihe transmitisse entusiasmo para viver." (IVO, 2007, p. 58.) Esse alguém será a datilógrafa Arlinda, que, no presente narrativo, dorme no regaço do funcionário público. Eis que se abre uma porta para o narrador, com a focalização a repousar em Rodolfo, recuperar vários momentos vividos pela personagem: "Rodolfo assistia, naquele momento, ao retornar silencioso de todo o seu passado. Contaria a Arlinda, algum dia, tudo que the acontecera? Ou guardaria, para sempre, aquela história?" (IVO, 2007, p. 58.) Em visitação à mente de Rodolfo, o narrador desvenda "aquela história", que passa por estudos no Recife (em que a esbórnia foi companheira assídua), um cargo de engenheiro agrônomo em União e, ainda na cidade do interior de Alagoas, por um idílio proibido com Dulce, mulher casada com o negociante Fulgêncio. "Repentinamente, tudo se esvaiu, e Rodolfo se viu no meio da sala. Tinham acabado de dançar, e Arlinda the apertava a não, num gesto de despertar." (IVO, 2007, p. 61.) Absorto nas lembranças convertidas em discurso pelo narrador, Rodolfo parece perder os sentidos, resultado, no juízo de Arlinda, da bebida. A carga do passado não o abandona, por mais que dela tente se desvencilhar.

Um outro exemplo é o do já aludido Moacir, que, mais que se vergar pelo peso de vivências anteriores, entrega-se mesmo a lucubrar sobre o tempo, o ser no mundo. Nesta sequência, já não é o narrador quem fala pela personagem, mas sim a própria; ou, melhor dito, os pensamentos da personagem se convertem em palavras sem que, expressamente, filtrem-se pela voz narrativa. Como preâmbulo à divagação, tem-se a voz da mente de Moacir: "E se alguém estivesse escutando meus pensamentos?" (IVO, 2007 , p. 61.); o que, com efeito, ocorre pelos parágrafos subsquentes, aspeados, em diferenciação ao que se dá com as rememorações de Rodolfo. Ao olhar-se no espelho - 
gesto que não deixa de indicar uma busca de autoconhecimento, dada a conjuntura da fábula -, Moacir vê:

Duas rugas enormes se estampavam em meu rosto, descendo das narinas para as comissuras dos lábios. Essas rugas são, parcialmente, o resultado de eu ter sorrido muito durante minha vida. Sorri enquanto passeava junto ao mar, sorri acompanhando enterros, enquanto passeava junto ao mar, sorri sentado na beira de uma cama, em um prostíbulo, sorri vendo a lua crescer entre árvores. E meus lábios se abriram para que eu sorrisse a pessoas bem diferentes.

De minha parte, não gostaria de, nesse instante, rememorar tudo isso. Mas não poderei proceder de outra maneira. Não é com prazer que reúno essas lembranças dispersas, esses fatos que trabalham silenciosamente em mim quando resolvo deitar-me. (IVO, 2007, p. 62.)

Aos 24 anos de idade, Moacir faz uma espécie de balanço de tudo o que viveu, em imagens que encavalgam boas e más experiências, momentos de prazer e dissabores; um ensemble que Moacir não consegue prover de sentido. "Impossível abarcar todas as coisas ao mesmo tempo, participar de tudo." (IVO, 2007, p. 63.) O presente se revela opressivo por conter tudo o que se foi e o que se é. A mudança, talvez um refrigério para oferecer motivações à existência, é igualmente vã; não apenas por não ter uma face definida (um futuro incerto), mas, mais radicalmente, por sua impossibilidade: "Sim, não poderei mudar. Muito tarde para esquecer a marcha dos anos que se desenrolaram uns após os outros." (IVO, 2007, p. 63.) Um jovem que se sente como um velho, porque vive em função de um passado não resolvido. E que encerra seus devaneios ao saber, por Jandira, da morte de Juquinha. O futuro, a esta altura, pode apenas significar o fim:

O Tempo devorara a festa. Era inútil revigorar as forças consumidas, encher de risos e de gritos o silêncio que se apoderava de tudo. Todos só pensavam no dia seguinte, onde uma hora ou um minuto certos os esperavam. (IVO, 2007, p. 81.)

Nada poderia ser mais cabalmente desesperançoso que a morte de uma criança; figuração de promessa, de planos, de realizações. O evento acaba por ser uma traduçãosíntese do estado de alma dos jovens que se reúnem para festejar. O "Tempo", assim, com inicial maiúscula, revela a sua inexorabilidade ("como um deus, [...] destruindo tudo."; IVO, 2007, p. 80) e de apenas um passado que não se converte em realizações se dispõe. Só depois, quando se torna romancista - ainda mais, premiado, reconhecido Moacir logra a visualização de um destino, possível pela capacidade de expressão (IVO, 2007 , p. 179; p. 195). No ofício de escritor, Moacir está doravante protegido, pelo seu ofício, das antigas expectativas e do tédio (IVO, 2007, p. 195). No romance, essa 
informação introduz a exposição de novas consternações da personagem principal. Ciente do sucesso do amigo, Jandira se vê frustrada e condenada "ao anonimato de uma vida sem linguagem" (IVO, 2007, p.195), da qual Moacir escapou com a publicação de uma obra sua. Para além de não se fixar no mundo por meio de um trabalho intelectual, Jandira sequer concebe um filho, não continua "em uma criatura do seu sangue" (IVO, 2007, p.196). O seu destino estava encerrado nela mesma, não se completaria em outra pessoa.

Ainda no que ao falecimento de Juquinha diz respeito, há um ponto a se assinalar: também o sentimento de ausência se apagará, numa outra reflexão expressa sobre o tempo que se desenvolve no discurso, desta vez, no capítulo 11:

[...] Jandira foi ao centro da cidade fazer compras e, no formigamento de uma rua cheia de casas de quinquilharias e de fazendas de cores berrantes, e de botequins que a nauseavam com os seus cheiros picantes, e que tinham algo de oriental em seu rumor febril de ofertas e pregões, ela reconheceu um rosto. Era o de Seu Francisco, o pai do menino que morrera na llha do Governador. la alegre, o braço agarrado a um homem em mangas de camisa que deveria ser algum negociante judeu ou turco. E a convicção de que o rodear dos dias e dos anos a tudo apagava, como uma borracha, a fim de que a vida pudesse continuar o seu caminho entre as luzes e as trevas, mais uma vez a humilhou, na grande tarde juncada pelo burburinho interminável do mundo. (IVO, 2007, p. 178-179.)

No barulho da cidade - que já não mais anima ou diverte, como se expectava, mas, sim, desconsola -, Jandira depara com um pai que perdeu o filho; e o parece perder duas vezes: uma para o mal, outra, para o bem. Todo o lamento da família quando da agonia da criança se converte em esquecimento reparador; é o que, ao menos, Jandira flagra no rosto despreocupado, alegre, de Seu Francisco. Aqui, a dor do pensamento é alçada à condição de divisor de águas entre as personagens. Contrastar um passado de alegria e de expectativas com um presente cruel acarreta o entristecimento e a falta de planos para Jandira; a não recuperação da dor de uma experiência passada significa seguir em frente, continuar a viver sem peias. Claro está, entrementes, que o fato de o ponto de vista repousar em Jandira diz muito da força - e do despropósito? - da constatação. Apenas por um semblante efêmero todo um entendimento sobre o tempo se constrói. Se apenas na curva de uma individualidade se pode sustentar uma visão de mundo, em Jandira, é a malfadada experiência do presente sem perspectivas que amplifica o quadro deparado. Não conhece, ela - nem ninguém -, o íntimo do pai que perdeu o filho. O estado de alma de Jandira é que a faz julgar, via voz do narrador, o homem e o poder do tempo. 
Absorvidos pela marcha inexorável do tempo, Jandira e José continuam em seu casamento, malgrado os dissabores que experienciam em sua condição. O capítulo 12 , derradeiro do romance, fixa uma imagem das duas personagens "Muitos anos depois [...]." (IVO, 2007, p. 243). Note-se que, neste momento, tem-se a convergência entre os três níveis narrativos, com discurso, enredo e fábula numa mesma esfera de tempo, fator estrutural que sinaliza a estabilidade também vivencial das personagens, numa demonstração de que o aprendizado sobre a existência as leva a perceber que as oscilações e as frustrações são constantes do homem diante da vida. Esse capítulo dá conta de indivíduos absorvidos pelas coisas cotidianas, mas, nem por isso, totalmente afastados da reflexão sobre o ser no mundo. De todo modo, parecem, à altura, ter aprendido a desfrutar do momento presente, no que tem de efêmero, mas, também, de vivaz:

Eles amavam os domingos porque passavam o dia longe do centro da cidade, sem nenhum laço a uni-los ao movimento das ruas, à atmosfera urbana, aos grandes edifícios que pareciam construídos para escravizar os homens a um cotidiano inglório e sem alegria. Tinham nascido para os domingos e sentiam que esses dias deviam ser aproveitados o mais possível, todos os minutos deveriam ser vividos mediante uma sabedoria eufórica e silenciosa. (IVO, 2007, p. 244.)

É o contraste com os dias comuns que faz com que o domingo tenha o seu valor salientado; pela manhã, praia; à tarde e à noite, passeios. O gozo do tempo presente, neste caso, é a revelação de que é preciso entender a natureza de cada tempo, o que antes parecia faltar, sobretudo, a Jandira. É importante assinalar que não se tem, nessa percepção, um sentido glorioso da existência, até mesmo por persistirem as inquietações da personagem feminina: "Sempre o relógio, a marcar horas, o tempo a caminhar, a devorar este instante, substituindo-o por outro que também morre. Sempre o Tempo." (IVO, 2007, p. 245.) Se o Tempo segue o seu ritmo - mas uma vez aquele que tudo domina, com inicial maiúscula -, o que resta ao ser humano é aprender o que fazer dele. Na praia, Jandira e José escutam "o avanço das vagas" (IVO, 2007, p. 245), imagem que remete ao tempo, recuperado quando, no mesmo dia, Jandira espera o sono: "[...] ficou pensando muito nas ondas, nessas ondas que, no mar escuro, avançavam sempre de encontro à terra, mesmo que nenhum olhar as contemplasse." (IVO, 2007, p. 247.) As ondas, em seu vaivém, em seu ciclo inerente (porque independente da percepção humana), projetam um entendimento do tempo em que se desenvolve à revelia do homem, talvez vergado diante de um peso que não pode compreender em plenitude. É, 
paradoxalmente, a compreensão do que não se pode entender, do que escapa, o que se traduz numa perda de referências.

\section{Considerações Finais}

É justo afirmar, assim, que a perda de referências com que depara o ser humano nos tumultuosos meados do século 20 consiste, em As Alianças, simultaneamente no modo de dizer e no dito. Tanto a elaboração da narrativa é plena de sentidos no que diz respeito às diversas configurações do tempo - numa ligação muito íntima à vivência das personagens, conforme se sustenta neste trabalho -, quanto a recorrente discussão do próprio tempo o transforma em tema do romance, no sentido de que está presente em várias vozes e em vários momentos da fábula. Essa integração, assim se pode julgar, evidencia os recursos de Lêdo Ivo como romancista; como se disse, sua face menos conhecida.

\section{Referências}

ADORNO, T. W. Posição do Narrador no Romance Contemporâneo. In: Notas de Literatura. São Paulo: Duas Cidades; 34, 2003. v.1, p. 55-63.

ANDRADE, M. O Leão Devorador. Graciliano, Maceió, n. 7, p. 5-7, nov.-dez. 2010.

ASAS do Desejo. Direção: Wim Wenders. Produção: Anatole Dauman e Wim Wenders. Roteiro: Peter Handke e Wim Wenders. Intérpretes: Bruno Ganz, Solveig Dommartin, Otto Sander, Curt Bois, Peter Falk e outros. São Paulo: Europa Filmes, 2007. 1 DVD (127 min.), color. 28min 20seg.

AUERBACH, E. Mimesis: a representação da realidade na Literatura Ocidental. São Paulo: Perspectiva, 1976.

BOURNEUF, R.; OUELLET, R. O Universo do Romance. Coimbra: Almedina, 1976.

HAMILTON, L. Some Recent Brazilian Literature. Modern Language Journal. Hoboken, v. 32, n. 7, p. 504-507, Nov. 1948.

IVO, L. As Alianças. Belo Horizonte: Leitura, 2007.

MENDILOW, A. A. O Tempo e o Romance. Porto Alegre: Globo, 1972.

SEGRE, C. Análise do Raconto. Lógica Narrativa e Tempo. In: As Estruturas e o Tempo. São Paulo: Perspectiva, 1986. p. 11-89.

SILVA, M. F. da. Romance e Negatividade Grávida na Ficção de Lêdo Ivo. Graciliano, Maceió, n. 7, p. 52-57, nov.-dez. 2010. 
A Geografia Literária de Lêdo Ivo: a cidade nos romances As Alianças e Ninho de Cobras. Maceió: [s.n.], 2007.

WAIZBORT, L. Erich Auerbach e a Condição Humana. In: ALMEIDA, J. de; BADER, W. (Orgs.). O Pensamento Alemão no Século $X X$ : grandes protagonistas e recepção das obras no Brasil. São Paulo: Cosac Naify, 2013. v. 2, p. 175-217. 